\title{
COMMUNITY PARTICIPATION DALAM MENJAGA KAWASAN HUTAN DI PROVINSI RIAU
}

\author{
Rahyunir Rauf \\ Dosen Program Studi IImu Pemerintahan, Fakultas Ilmu Sosial dan Ilmu Politik \\ Universitas Islam Riau \\ rahyunir.ip@soc.uir.ac.id \\ Zainal \\ Dosen Program Studi IImu Pemerintahan, Fakultas Ilmu Sosial dan Ilmu Politik \\ Universitas Islam Riau \\ zainal.ip@soc.uir.ac.id \\ Data Wardana \\ Dosen Program Studi IImu Pemerintahan, Fakultas Ilmu Sosial dan Ilmu Politik \\ Universitas Islam Riau \\ dw17@soc.uir.ac.id \\ Sri Maulidiah \\ Dosen Program Studi Ilmu Pemerintahan, Fakultas IImu Sosial dan Ilmu Politik \\ Universitas Islam Riau \\ sri.ip@soc.uir.ac.id
}

\begin{abstract}
Abstrak
Secara empiris kita dapat amati begitu banyaknya persoalan kehutanan yang terjadi di Provinsi Riau mulai dari kebakaran hutan, illegal loging serta mengganti fungsi hutan itu sendiri ke dunia bisnis sehingga hutan hanya ditumbuhi pohon akasia dan sawit. Persepsi publik di Indonesia menganggap bahwa Provinsi Riau merupakan Provinsi yang kaya raya akan tetapi tidak demikian faktanya ini terlihat dari masih banyaknya masyarakat Riau yang hidup dengan kondisi miskin. Kajian ini bertujuan untuk menelaah secara mendalam tentang Community participation dalam menjaga kawasan hutan yang ada di Provinsi Riau. Metode yang penulis gunakan dalam penelitian ini menggunakan metode kualitatif dengan tipe deskriptif serta pengumpulan data dilakukan dengan kajian literature review dari jurnal-jurnal yang sudah publish. Hasil penelitian ini menunjukan bahwa kehadiran perusahaan di tengah-tengah masyarakat sama sekali tidak mendatangkan manfaat apapun kepada masyarakat yang tinggal di sekitaran kawasan konsesi maupun di sekitaran kawasan perusahaan sawit yang begitu banyak di Provinsi Riau. Kemudian baik langsung ataupun tidak langsung dunia usaha dan pemerintah merupakan aktor yang berkontribusi terhadap kerusakan hutan yang ada di Provinsi Riau. Peneiltian ini disimpulkan bahwa Community participation yang ada di Provinsi Riau tidak bisa terlalu banyak berkontribusi dalam menjaga kawasan hutan secara komprehensif karena semua kewenangan bidang kehutanan berada di Pemerintah Pusat. Saran ini yaitu pemerintah harus lebih serius dan fokus dalam menjaga kawasan hutan dari pengrusakan yang terjadi di Provinsi Riau dan jangan bernegosiasi dengan swasta.
\end{abstract}

Kata Kunci : Partisipasi Publik, Pengrusakan dan Kehutanan 


\section{Pendahuluan}

Dalam menjaga kawasan hutan yang ada di Indonesia Community participation menjadi penting karena hampir tidak pejabat publik yang betul-betul terlihat serius menjaga kawasan hutan yang ada di Indonesia bahkan sebaliknya Kementerian Lingkungan Hidup dan Kehutanan Republik Indonesia memliki target dalam program kegiatannya untuk memperluas pengembangan kawasan hutan untuk dikelola oleh dunia swasta ini secara sederhana dapat kita interpretasikan pemerintah berkontiribusi sangat besar dalam melakukan pengrusakan kehutanan secara legalitas berupa kebijakan yang mereka keluarkan di Indonesia.

Dengan berlakunya kebijakan Nomor 23 Tahun 2014 tentang pemerintahan daerah ini menjadi semacam angin segar bagi dunia usaha karena untuk mengelola kawasan hutan mereka tidak perlu lagi berurusan dengan pemerintah Provinsi dan pemerintah Kabupaten akan tetapi selesai urusan mereka di Kementrian Lingkungan Hidup dan Kehutanan (KLHK) sehingga daerah hanya menerima dampak konfliknya saja baik itu konflik horizontal maupun konflik secara vertikal.

Disamping problem di atas penegakan hukum bagi pelanggar ataupun aktor-aktor yang secara sengaja melakukan pengrusakan terhadap hutan yang ada di Provinsi Riau juga setengah hati melakukan eksekusi terhadap para aktor-aktor dunia usaha seperti yang melakukan pembakaran hutan, seolah hukum begitu tumpul menghadapi para pemilik modal dan begitu tajam ketika yang melakukan pembakaran hutan itu adalah masyarakat biasa. Sehingga kita masih ingat Kapolda Riau mengeluarkan surat penghentian penyidikan perkara (SP3) kepada perusahaan yang sudah jelas melakukan pengrusakan hutan tersebut.

Community participation menjadi penting karena hanya masyarakat kawasan hutan yang betul-betul serius menjaga kawasan hutan itu dari pengrusakan dan dari tangan-tangan yang tidak bertanggung jawab, akan tetapi tidak juga menutup kemungkinan masih ada di beberapa wilayah di Provinsi Riau terdapat masyarakat yang menebang hutan dalam rangka menyambung hidup mereka dan untuk menyekolahkan anak-anak mereka. Bagi penulis ini merupakan hal yang biasa karena pengrusakan seperti ini tidak terlalu berdampak buruk terhadap pengrusakan kawasan hutan karena mereka melakukan itu karena tidak ada pilihan lain dan sekali lagi peneliti tegaskan mereka hanya untuk meyambung hidup dan bukan untuk menjadi kaya raya. 
Community participation menjadi sangat bermakna ketika di salah satu desa yang ada di Kabupaten Kepulauan Meranti tidak memberikan sama sekali ruang kepada perusahaan untuk masuk dan beroperasi di wilayah mereka karena dari peta wilayah atau izin konsesi yang dimiliki oleh perusahaan rumah masyarakat dan kebun masyarakat semuanya masuk dalam wilayah konsesi perusahaan dan ditambah lagi gambut di Kabupaten Kepulauan Meranti memiliki kedalaman yang rata-rata di atas 2 meter dan ini merupakan wilayah yang tidak boleh ditanami akasia.

Dari berbagai problem empiris yang sudah penulis jabarkan di atas kajian ini menjadi menarik untuk diteliti baik secara empiris maupun secara teroritis dengan demikian penulis akan melakukan kajian penelitian dengan judul "Community participation Dalam Menjaga Kawasan Hutan Di Provinsi Riau".

\section{Tinjauan Pustaka}

Community participation baik secara konsep ataupun secara teroritis begitu banyak yang menjelaskan pengertiannya secara spesifik akan tetapi disini peneliti lebih fokus menjelaskan dan menjabarkan beberapa penelitian terdahulu yang menggunakan Community participation sebagai konsep utama dalam menganalisis persoalan penelitiannya.

Salah satu aspek yang harus dipenuhi adalah adanya partisipasi masyarakat dalam program-program pemerintah. Adanya partisipasi masyarakat dalam setiap program pemerintah akan dapat mendorong tercapainya tujuan-tujuan pembangunan nasional maupun daerah. Salah satu bagian yang terpenting adalah mewujudkan partisipasi masyarakat di bidang kesehatan (Laksana, 2013).

Perlunya bawahan diberi kesempatan untuk berpartisipasi dalam proses penyusunan anggaran karena menurutnya partisipasi dalam penyusunan anggaran diyakini dapat meningkatkan kinerja aparat pemerintah daerah. (Agusti 2012).

Model-model partisipasi publik diharapkan dapat memberikan kesempatan untuk mengembangkan pelayan publik yang memperhatikan prinsip-prinsip demokrasi, transparansi, akuntabilitas, tanggung jawab, dengan paradigma pelayanan publik yang baru. (Larasari 2008).

Partisipasi masyarakat baik dalam pembangunan maupun pengelolaan sampah sangat dibutuhkan. Oleh karena itu dalam melaksanakannya, pemerintah desa harus melibatkan masyarakat agar suatu kebijakan dapat berjalan semestinya. (Hernawati 2013). 
Sistem Informasi Penilaian (SIP) Bandung Juara merupakan aplikasi berbasis teknologi informasi yang bertujuan memudahkan dalam evaluasi pencapaian kontrak kinerja kecamatan. SIP Bandung Juara ini pula sebagai wadah partisipasi publik dalam menilai kinerja layanan publik yang dilakukan kecamatan di Kota Bandung. (Sagita 2016).

Partisipasi masyarakat merupakan suatu proses kegiatan yang dilakukan oleh perorangan maupun secara berkelompok atau masyarakat. Untuk menyatukan kepentingan atau keterkaitan mereka terhadap organisasi atau masyarakat yang bergabung dalam rangka pencapaian tujuan masyarakat itu sendiri. (Akbar, Suprapto, and Surati 2018).

Partisipasi merupakan salah satu unsur penting yang harus diperhatikan dalam kebijakan. Undang- Undang No.10 tahun 2004 tentang Pembentukan Peraturan Perundang-undangan, dalam pasal 53 secara jelas mengatur mengenai Partisipasi Masyarakat dalam Pembentukan Peraturan Perundang-undangan termasuk Perda. Partisipasi ini merupakan salah satu bentuk partisipasi politik masyarakat yang sangat penting dalam rangka menciptakan good governance. Oleh karena itu pelaksanaan partisipasi publik dalam pembentukan kebijakan haruslah diatur secara lebih jelas. (Erman I. Rahim 2004).

Partisipasi Masyarakat Menuju Rehabilitasi Hutan Bakau (Studi Tentang Peran Pemerintah dalam Meningkatkan Partisipasi Masyarakat dalam Rehabilitasi Hutan Mangrove dalam Agen Lingkungan di Kota Probolinggo). Hutan bakau di Kota Probolinggo semakin terdegradasi dan rusak karena pembangunan dan kegiatan masyarakat setempat. Pemerintah Probolinggo melalui Agen Lingkungan merehabilitasi hutan mangrove berdasarkan partisipasi masyarakat. (Pribadiningtyas 2013).

Proses pengawasan keuangan daerah (APBD) merupakan kegiatan yang sangat penting, agar pengawasan keuangan daerah (APBD) menjadi baik maka harus ditunjang dengan pelaksanaan akuntabilitas publik, partisipasi masyarakat, dan transparansi kebijakan publik yang baik juga.(Nurmalita 2000).

Partisipasi masyarakat memiliki posisi yang sangat penting dalam perencanaan pembangunan, karena pada dasarnya masyarakat adalah pihak yang paling mengetahui masalah dan kebutuhan sendiri. Oleh karena itu perencanaan pembangunan yang partisipatif menjadi amanat undang-undang yang harus dilakukan oleh pelaku pembangunan yang diregulasikan (Sigalingging and Warjio 2014). 
Partisipasi masyarakat menjadi prasyarat utama. Hal ini mencakup semua aspek pelaksanaan pembangunan di daerah mulai dari perencanaan hingga pengawasan. Partisipasi masyarakat inilah yang mendorong proses demokratisasi dapat berjalan dengan lancar. Jika dianalisa secara teoritis, teori sistem David Easton sudah mewakili gambaran pentingnya partisipasi masyarakat dalam pembuatan ataupun perubahan kebijakan. Secara sederhana Easton memaparkan bahwa proses input yang berasal dari tuntutan dan dukungan masyarakat, kemudian dikonversikan oleh lembaga pembuat kebijakan, barulah dapat melahirkan output berupa kebijakan publik yang diberlakukan kepada masyarakat. Hal ini selanjutnya berproses lagi dengan pengaruh dari lingkungan dalam dan luar dari masyarakat tersebut dan pada akhirnya melahirkan input baru.(Magriasti 2011).

Perencanaan partisipatif sebagai strategi pembangunan dan proses penentuan keputusan publik sangat bergantung pada kesadaran masyarakat untuk mau melibatkan diri dalam proses pembangunan. Keberhasilan dalam pembangunan ditentukan faktor sosial dan politik, meliputi: public trust, legitimacy, accountability, public service quality dan public disobedience. Partisipasi dan transparansi akan menjadi perangkat untuk mengembalikan kepercayaan masyarakat pada pemerintah dan legitimasi sendiri dipahami sebagai pengakuan dan dukungan dari rakyat.(Lubis 2009).

Menurut Cohen dan Uphoff (1977) dalam (Sagita 2016) partisipasi masyarakat dapat dibedakan atas 4 jenis yaitu a) participation in decision making; b) participation in implementation; c) participation in benefits; d) participation in evaluation. Participation in decision making merupakan keterlibatan masyarakat dalam memberikan masukan pemikiran terkait perencanaan program kerja dan kebijakan pemerintah. Selanjutnya, Participation in implementation merupakan keterlibatan masyarakat untuk ikut serta dalam mendukung terlaksananya kebijakan baik kontribusi dalam memberikan tenaga, bahan baku maupun finansial dengan memberikan sumbangan pembiayaan bagi terselengaranya pembangunan. Bentuk partisipasi berikutnya adalah Participation in benefits yang merupakan bentuk keterlibatan masyarakat untuk turut menikmati dan memanfaatkan hasil hasil kebijakan yang sudah dilaksanakan. Partisipasi yang terakhir adalah participation in evaluation yakni bentuk partisipasi masyarakat melalui keikutsertaan mengawasi kegiatan dan menilai kinerja kebijakan serta hasil-hasilnya.

The development of Community participation in China? Needless to say, a primary difference in the operating context and the background to participatory initiatives is that, unlike most other states recently embarking on participatory processes, 
economic reform has preceded sociopolitical reform in China, and economic rights are prioritized over social and human rights. This places the participatory activity - which is fundamentally concerned with inclusion and social equity - on a different footing.(Plummer \& Taylor: 2004).

Dari berbagai penelitian terdahulu dan konsep yang sudah jelaskan di atas maka penelitian ini menggunakan konsep Community participation menurut Turner dan Hulme (1997) yang menyebutkan Community participation terbagi dalam dua dimensi yaitu dimensi desentralisasi dan dimensi hubungan pemerintah dan masyarakat.

\section{Metode Penelitian}

Untuk mempermudah penyelesaian penelitian ini maka peneliti menggunakan metode kualitatif karena dengan menggunakan metode penelitian kualitatif maka peneliti akan mampu menggali secara mendalam berbagai informasi dan data-data yang dibutuhkan untuk kepentingan penelitian. Kelemahan penelitian kuantitatif hanya mampu memberikan hasil penelitian berupa angka-angka dan presentasepresentase sehingga secara empiric tidak menyentuh kepada inti dari persoalan penelitian. Serta untuk mempermudah peneliti mendapatkan informasi terkait penelitian ini maka peneliti akan menggunakan mendeley untuk mencari berbagai referensi yang relevan dengan penelitian ini. Serta problem empiris yang akan peneliti interpretasikan dari berbagai tanggapan informan yang ada di dalam penelitian. Dengan demikian peneliti beranggapan bahwa statement yang disampaikan pejabat publik di media itu jauh memliki kualitas informasi yang baik ketimbang peneliti menjumpai secara langsung dan bertanya secara langsung dengan informan yang terlibat di dalam penelitian ini.

\section{Pembahasan}

Community participation dapat diartikan sebagai keterlibatan mental dan emosional seorang individu dalam situasi kelompok tertentu yang mendorongnya untuk berkontribusi untuk mencapai tujuan kelompok dan berbagi tanggung jawab di dalam pencapaian tujuan. Bahwa kontribusi masyarakat dalam pencapaian tujuan dilakukan dalam tiap-tiap tahapan mulai dari perencanaan perumusan agenda kerja pemberian izin, pelaksanaan pembangunan pemberian izin, hingga evaluasi kegiatan pemberian izin.

Berdasarkan definisi yang dinyatakan di atas maka paradigma penyelenggaraan pemerintahan saat ini memberikan peluang bagi masyarakat untuk ikut berkontribusi merencanakan, mensukseskan, dan mengevaluasi pemberian izin kepada dunia usaha dan juga dapat mengevaluasi kinerja yang dilakukan oleh 
pemerintah. Dengan melakukan tindakan-tindakan tersebut, berarti masyarakat sudah turut aktif memikirkan pemenuhan kebutuhan hidup dan penghidupannya demi masa depan yang lebih baik.

Selain itu community participation juga dapat terwujud apabila diminta, artinya community participation ada apabila pemerintah meminta atau memaksa masyarakat untuk melakukannya. Community participation bentuk lain adalah keterlibatan masyarakat atas adanya timbal balik finansial atau karena adanya insentif, yakni community participation yang dilakukan masyarakat bukan atas kesadaran sendiri melainkan adanya iming-iming bayaran atau insentif tertentu apabila dilakukan. Untuk melakukan kajian pembahasan mengenai community participation dalam penelitian ini maka akan dijelaskan dalam dua dimensi yang ada yaitu aspek desentralisasi dan aspek hubungan pemerintah dan masyarakat.

\subsection{Desentralisasi}

Desentralisasi diartikan sebagai lawan dari sentralisasi karena pemakaian kata "de" dimaksud untuk menolak kata sebelumnya yaitu sentralisasi. Unsur menolak atau berlawanan terkait dengan penyelenggaraan pemerintahan daerah yang menyebabkan desentralisasi merupakan antitesa dari sentralisasi. Desentralisasi adalah pembagian dari sebagian kekuasaan pemerintah oleh kelompok yang berkuasa di pusat terhadap kelompok-kelompok lain yang masing-masing memiliki otoritas di dalam wilayah tertentu di suatu negara. Dari penjelasan tersebut peneliti dapat menginterpretasikan bahwa kebijakan bidang kehutanan seperti dari sistem sentralisasi ke sistem desentralisasi dan kembali lagi ke system sentralisasi.

Terlepas dari kesamaan asalnya program kehutanan masyarakat secara terpusat dan pengelolaan lokal sangat berbeda dalam implikasinya terhadap masyarakat di sekitaran konsesi hutan tanaman industri. Berlawanan dengan pengelolaan hutan kemasyarakatan, kebijakan pengelolaan bersama atau devolusi yang berupaya mempertahankan kontrol atas keputusan penting serta manfaat sektor kehutanan, desentralisasi memberi peluang keterlibatan pengguna hutan dalam kegiatan politik yang lebih luas dan mempengaruhi negara dalam dominasi historisnya.

Berdasarkan wawancara yang penulis lakukan dengan dengan Kepala Desa Kesuma di daerah Taman Nasional Teso Nilo Kabupaten Pelalawan yang menyampaikan: Pada saat hutan di daerah kami ini statusnya menjadi kawasan Taman Nasional Teso Nilo (TNTN)secara aturan yang berlaku kami masyarakat disekitar hutan tidak boleh menebang sebatangpun kayu di hutan, karena itu merupakan milik negara dan kami juga sangat dilarang melakukan kegiatankegiatan lain namun semenjak PT. RAPP menguasai hutan tersebut mereka bebaslah 
kami menabang kayu apa saja dan perusahaan juga bebas menebang dalam jumlah yang lebih luas.

Pernyataan tersebut juga di dukung oleh kepala desa Gondai Zulfahmi yang menyampaikan: Kami yang berada di sekitar kawasan hutan ini tidak mampu berbuat banyak karena kebijakan yang dilakukan oleh pemerintah sudah jelas segala sesuatu nya berada di tangan pusat. Dan kami masyarakat desa yang berada di sekitaran kawasan hutan merasa hutan di sekitaran kami ini sebelum menjadi status kawasan TNTN bisa mengambil kayu untuk keperluan membuat rumah dan keperluan lainnya setelah statusnya menjadi TNTN semuanya dilarang mengambil kayu yang ada di kawasan TNTN tersebut.

Desentralisasi dapat berfungsi sebagai pemersatu pemerintah dengan masyarakat seraya memupuk perjuangan di dalam diri masyarakat. Saling ketergantungan tersebut menciptakan tantangan dan peluang yang khusus bagi masyarakat yang tinggal di dalam dan di sekitar kawasan hutan. Beberapa pertimbangan yang perlu dilakukan oleh Pemerintah hendaknya melibatkan community participation di sekitar kawasan hutan.

Terbentuknya pemerintah setempat meningkatkan kehadiran negara pada tingkat pemerintah daerah. Bila kehadiran di tingkat pemerintah daerah disertai dengan kewenangan yang kuat, kemampuan masyarakat sekitar hutan untuk bertindak secara semi-otonom akan berkurang. Namun masyarakat harus terlibat lebih langsung dengan negara untuk menjaga pengaruhnya atas pengelolaan hutan serta lebih berpengaruh dalam urusan kepemerintahan

Para elit pemerintah daerah provinsi dan pemerintah kabupaten bisa mengkooptasi atau berkolusi dengan swasta demi kepentingan sendiri, termasuk merebut sumberdaya penting yang dimiliki masyarakat di sekitaran kawasan hutan. Untuk memperkuat pemanfaatan keterkaitan ini, negara harus kuat untuk melindungi masyarakat dari kekuasaan para elit, maupun ketidakadilan yang dirasakan masyarakat sekitaran kawasan hutan. Namun masyarakat juga harus kuat untuk menerapkan wewenang sipil mereka atas urusan publik. Meningkatnya kehadiran serta keterkaitan negara akan paling terasa bagi masyarakat yang secara fisik dekat dengan pemerintah daerah. Bagi masyarakat daerah terpencil, perubahan yang ada mungkin sangat terasa, karena yang langsung meraskan dampak kehadiran perusahaan adalah mereka. Para stakeholders yang terlibat dari unsur pemerintah antara lain pemerintah pusat dalam hal ini kementerian lingkungan hidup dan kehutanan, pemerintah provinsi riau, pemerintah daerah kabupaten kepulauan meranti. Kemudian stakeholders dari unsur swasta adalah pemerintah PT. RAPP yang memiliki izin hutan tanaman industry di kabupaten kepulauan meranti khususnya di pulau padang dan stakeholders dari unsur masyarakat adalah 
masyrakat desa yang tinggal di daerah Kawasan konsesi. Selama ini dalam proses pemberian izin usaha yang diberikan oleh pemerintah kepada swasta tanpa melibatkan masyarakat yang tinggal di Kawasan konsesi.

Desentralisasi dapat menyebabkan perpecahan dan melemahkan negara terutama selama proses transisi kebijakan. Agar negara tetap dominan dibutuhkan hubungan horizontal dan vertical yang efektif antara pemerintah pusat dan pemerintah daerah. Bila hubungan tersebut tidak ada, pemerintah daerah akan bertindak seperti semi-otonomi. Pemerintah daerah khususnya Dinas Lingkungan Hidup dan Kehutanan Provinsi Riau sering bertindak seolah tidak ada pilihan lain, negara yang terpecah memudahkan korupsi pemerintah daerah dan sektor swasta.

Desentraliasi lebih mendekatkan negara karena para pejabat terikat hubungan kekerabatan dan sejarah pribadi, pertemanan, saling ketergantungan ekonomi dan hubungan kekuasaan setempat dengan masyarakat sekitaran kawasan hutan. Meskipun hal ini mengurangi kekuasaan negara dan lebih memungkinkan kooptasi pejabat setempat. Hubungan pribadi itu juga dapat lebih memudahkan negara dan masyarakat berhubungan, mendorong komunikasi, pemahaman dan pelibatan yang setara namun dalam fakta nya itu semua tidak sesuai dengan kenyataan yang ada.

Berdasarkan wawancara yang penulis lakukan dengan mantan Sekretaris Desa Lukit Kabupaten Kepulauan Meranti Junaidi menyampaikan bahwa: Kami disini tidak ada dilibatkan oleh pemerintah pusat dan pemerintah daerah karena dengan sistem yang ada sekarang perusahaan itu memiliki hubungan yang sangat erat dengan pemerintah, kami masyarakat sudah berupaya mencoba untuk menentang hanya saja kalau sekarang perjuangan kami sudah mentok dan masuk dalam masa melemah. Karena perusahaan sekarang sudah selesai menanam sekitar 20.000 hekter tanaman akasia baru di daerah kami ini. Peraturan yang dikeluarkan oleh kementerian lingkungan hidup tidak boleh bagi perusahaan menanam pada Kawasan gambut yang kedalaman gambutnya melebihi 3 meter akan tetapi peraturan yang dikeluarkan oleh kementerian kehutanan boleh menanam pada Kawasan gambut yang kedalamannya tidak melebihi kedalaman tiga meter, dan Ketika dua kementerian ini menjadi satu maka peraturan kementerian kehutanan dan izin hutan tanaman industry yang dikuasai oleh PT. RAPP di Kawasan teso nilo kabupaten pelalawan izinnya dicabut oleh kementerian kehutanan sehingga mengakibatkan lahan tersebut menjadi lahan tidur dan perusahaan RAPP harus angkat kaki dari wilayah konsesi tersebut.

Desentralisasi yang diberikan oleh pemerintah pusat kepada pemerintah daerah yang masih lemah, serta mulai menghilangnya nilai tradisional dan identitas masyarakat asli memungkinkan kelompok tradisional atau budaya lokal lebih menjadi bagian lebih diakui secara politis, terutama bila skala pengaruhnya sama 
dengan pengaruh pemerintah daerah. Kecendungan ini memperkuat hubungan pribadi antara masyarakat sekitaran konsesi hutan dan para aktor-aktor. Ketika terjadi kekacauan perimbangan kekuasaan atau ketegangan antar kelompok, pejabat pada tingkat pemerintah daerah mungkin tidak mampu menjaga kestabilan kekuasaan politisnya.

Desentralisasi membatasi peluang masyarakat mengorganisasi prakarsa politis dalam skala besar namun meningkatkan peluang mengorganisasinya di tingkat pemerintah daerah. Hal itu akan melahirkan tatanan politik lokal dengan wewenang dan kapasitasnya sendiri. Pemerintah daerah maupun kekuatan sosial mencari cara penggalangan dan mobilisasi masyarakat dan sumberdaya untuk meningkatkan pengaruh. Arena dan sarana pelibatan di tingkat daerah menjadi lebih penting pemerintah pada tingkat pusat.

Berdasarkan wawancara yang penulis lakukan dengan Junaidi juga menyebutkan bahwa: Sekarang kondisi di desa kami telah terjadi konflik horizontal, kami dengan kami yang sekarang sedang saling menghadang, pihak yang dulunya berpihak kepada rakyat sekarang sudah ditarik oleh perusahaan dan mendapatkan jabatan strategis dari perusahaan, sehingga para pejuang yang dulu nya vocal menyuarakan penolakan terhadap konsesi hutan penolakan PT. RAPP sekarang sudah berubah haluan menjadi pembeking perusahaan.

Hal senada juga ditambahkan oleh Effendi Kepala Desa Sungai Tohor mengatakan bahwa: Salah satu kesalahan yang dimiliki oleh pemerintah daerah dalam pemberian konsesi adalah ketika izin diberikan mereka hanya melihat dari atas dengan menggunakan helicopter sehingga kalau dari atas yang terlihat memang hanya hutan semua akan tetapi jika dilihat dari jalur darat yang mereka katakan hutan itu adalah kebun sagu masyarakat.

Munculnya pendukung perusahaan di tingkat desa juga sebagai pemicu konflik horizontal antara masyarakat dengan masyarakat yang ada di sekitaran kawasan hutan hal itu terjadi karena ketidakstabilan dan mendorong terjadinya penyesuaian dan pergeseran kelompok-kelompok yang dulu sebagai penolak perusahaan sekarang telah berubah sebagai pendukung perusahaan. Ditambah lagi ketegangan itu timbul dari posisi pemerintah daerah berada pada posisi di belakang perusahaan dan bukan di belakang masyarakat yang berada di kawasan hutan.

Kebijakan pemerintah pusat dan pemerintah daerah rentan berkonflik, namun ketergantungan antara pusat dan daerah tetap kuat, keduanya saling ingin memiliki sumberdaya. Di wilayah hutan tanaman industri yang ada pemerintah pusat enggan menyerahkan pendapatan dari kayu dan produk hutan yang bernilai tinggi, sedangkan pemerintah lokal memerlukan pasar, keahlian, dan modal yang kesemuanya tersedia di pusat. 
Berdasarkan kajian bidang kehutanan yang dilakukan Wollenberg dkk, (2009) juga menjelaskan bahwa semua keadaan terjadi dalam pemberian izin konsesi menciptakan peluang bagi masyarakat di sekitaran kawasan hutan untuk mempengaruhi negara dengan cara yang baru, gabungan antara jalur formal dan informal. Jalur informal melalui keterlibatan langsung, hubungan pribadi, wewenang tradisonal atau adat dan organisasi politik lokal sedangkan mekanisme formalnya melalui pemilihan umum atau pun partisipasi dalam dengar pendapat publik. Kontrol maupun monopoli oleh pemerintah pusat tidak bersifat absolut. Pemerintah pusat, pemerintah daerah, swasta maupun masyarakat tidak bisa saling mendominasi. Pengelolaan menjadi bersifat multi-kutub, multi-lapis dan bercirikan adanya berbagai pertarungan berbagai aktor. Desentralisasi memungkinkan masyarakat di sekitaran kawasan hutan mampu menjaga hutan dari berbagai pengrusakan yang dilakukan oleh dunia usaha.

\subsection{Hubungan Pemerintah dan Masyarakat}

Hubungan dibahas disini adalah hubungan yang terjadi antara yang memberi perintah dengan yang menerima perintah, pada berbagai posisi dan melakukan berbagai peran satu dan peran yang lain, baik timbal balik maupun searah, seimbang maupun tidak. Hubungan pemerintah dan masyarakat mengikuti pola pada umumnya, baik dalam bentuk sistem komunikasi maupun dalam bentuk siklus. Pemerintah pusat dalam hal ini kementerian lingkungan hidup dan kehutanan republik Indonesia memiliki kepentingan ataupun kepentingan program untuk mengembangkan wilayah hutan di Indonesia agar lebih produktif dan memiliki sumber pendapatan bagi negara, sementara masyarakat yang berada di Kawasan konsesi yang sudah dimiliki izin oleh perusahaan tidak mau lahan kebun mereka, rumah mereka agar tidak masuk ke dalam Kawasan konsesi akan tetapi faktanya yang terjadi di kabupaten kepulauan meranti banyak lahan masyarakat, rumah masyarakat yang masuk ke dalam Kawasan izin konsesi yang dikuasai oleh pihak swasta sehingga masyarakat di daerah tersebut tidak menerima kehadiran perusahaan yang menguasai banyaknya lahan masyarakat yang masuk ke dalam Kawasan konsesi.

Hubungan pemerintah dengan masyarakat berfungsi sebagai pengikat, penghubung, pembeda dan pembatas antara pemerintah dengan yang diperintah. Melalui hubungan ini disalurkan informasi dari pihak kesatu ke pihak yang lain, perintah dari atas dan laporan dari bawah, dan seterusnya. Hubungan itu merupakan sasaran pengamatan dan kajian materia dan forma paradigmatik Ilmu Pemerintahan. Apabila yang diperintah bertindak sebagai demander tetapi pemerintah menolak untuk menjadi supplier atau pemerintah mengecewakan yang 
diperintah, baik dalam hal pemberian izin hutan tanaman industri maupun dalam hubungan pemerintah dan masyarakat menjadi retak dan putus hubungan. Jika ini terjadi berarti malapetaka bagi yang diperintah maupun bagi yang memerintah.

Selanjutnya Ketua Lembaga Adat Melayu Riau Datuk Al-Azhar Setia Amanah menyebutkan bahwa: Riau ini merupakan negeri yang kaya di atas tanah ada minyak sawit dan di dalam tanah ada minyak bumi, namun begitu disayangkan bahwasanya kekayaan itu tidak terlalu memberikan dampak positif bagi masyarakat. Khusus untuk perusahaan yang bergerak di bidang hutan tanaman industri dan perusahaan yang bergerak di bidang sawit saat ini mereka telah menguasai jutaan hekter lahan di Riau yang sudah ditanami oleh akasia dan sawit, namun tidak mendatangkan manfaat dalam rangka memberikan kesejateraan bagi masyarakat tempatan. Seharusnya dalam kondisi seperti ini negara harus bisa hadir memberikan konstribusinya dalam memberikan pengaruhnya untuk menekan swasta agar hasil alam yang dikuras itu bisa dirasakan oleh masyarakat dampaknya. Dan yang terjadi malah limbahnya saja yang diterima oleh masyarakat ini artinya masyarakat malah merasakan ketidaknyamanan dengan datangnya perusahaan-perusahaan tersebut dengan melakukan eksploitasi di wilayah mereka.

Pernyataan yang sama juga di dukung oleh sekretaris Jikalahari Riau Made Ali yang menyebutkan bahwa: Perusahaan swasta seperti PT. RAPP itu sudah sangat mempunyai hubungan yang erat dengan pemerintah mulai dari tingkat yang paling rendah sampai ke tingkat istana sehingga kepentingan rakyat sudah tidak lagi terlalu diperdulikan oleh mereka. Bahkan perusahaan tersebut masuk ke kampuskampus memberikan bantuan buku, beasiswa, dan ke masjid-masjid memberikan bantuan Al-Qur'an dan bahkan sampai para wartawan diberangkatkan umroh ke tanah suci Mekkah. Jadi memang kejahatan-kejahatan coorporate ini tidak terlalu sampai kepada publik karena memang negara kita hari ini lebih berpihak kepada pihak perusahaan yang memiliki kekuatan financial yang tak terhingga.

Selanjutnya Koordinator Base Data and Adminitrastion Wahana Lingkungan Hidup Riau Fandi Rahman juga menyampaikan: Perusahaan saat ini sudah menguasai seluruh aspek yang ada, mereka mampu berdiri sejajar dengan pemerintah dan bahkan mereka juga mampu untuk melawan pemerintah. Pekerjaan yang berat bagi menteri sekarang menyelesaikan masalah sektor kehutanan mengingat dinamika sektor kehutanan yang ada adalah ibarat mengurai benang kusut yang sudah lama terjadi. Hal ini terjadi karena penguasa di masa lampau dengan sangat mudah memberikan izin jutaan hekter kepada Taipan sang pemilik modal. Jadi ini murni kesalahan dari negara yang seharusnya mendahulukan kepentingan masyarakat dari pada kepentingannya swasta. 
Ketika pemerintah dan pihak yang berwenang lemah, kelompok masyarakat menerapkan prinsip, norma, aturan dan praktik mereka sendiri dan secara selektif mematuhi atau mengesampingkan hukum negara. Kelompok demikian bertindak sebagai bidang sosial yang semi otonom Moore (1973). Di Riau McCartly (2000) juga menyebutkan bahwa para pemimpin politik setempat secara terbuka mengatur pembalakan yang dianggap legal. Meskipun membuka peluang bagi masyarakat di sekitaran hutan untuk mampu mempengaruhi lingkungannya, otonomi demikian tidak memberi peluang keterlibatan masyarakat dalam kerangka politik yang lebih luas.

Ketika kehadiran negara dan yang berwenang kuat, masyarakat lokal berupaya mempengaruhi pejabat setempat melalui senjata kaum lemah yaitu mengkooptasi pejabat membangun jejaring patron-klien pribadi dengan pejabat mengabaikan dan melaksanakan kebijakan secara buruk Manor (1999). Pada kasus ektrim, yang digunakan adalah protes dengan membakar, merusak, mengambil, mencabut bibit, dan menyita peralatan.

Hubungan antara pemerintah dan masyarakat dalam menjaga kawasan hutan di Provinsi Riau tidak terlepas dari banyaknya dinamika yang terjadi. Hampir disemua lokasi perusahaan melakukan konsesi dan sawit menimbulkan benih-benih konflik dan bahkan terjadi konflik besar-besaran. Suhaimi mantan pejabat di kehutanan Kabupaten Kepulauan Meranti menyebutkan bahwa: Beberapa titik wilayah yang dikuasai PT. RAPP di Kabupaten Kepulauan Meranti baik di desa Gunung Tohor atau pun di Desa Lukit Pulau dan Pulau Padang terjadi karena penolakan yang kuat dari masyarakat tempatan. Karena ketika perusahaan datang dan negara berada posisi pendukung perusahaan masyarakat merasa sangat dirugikan dengan datangnya perusahaan tersebut karena hanya dengan memegang selembar surat perusahaan bisa menguasai puluhan ribu hekter dan menebang habis kebun sagu yang dimiliki masyarakat.

Selanjutnya pernyataan itu juga di dukung oleh Kepala Desa Lukun Rauf yang menyebutkan bahwa: Kelemahan negara dalam menjaga hutan yang ada adalah karena peta yang mereka pegang adalah peta sejak tahun 1970 artinya kalau digunakan untuk tahun 2015 itu tentu sudah jauh berubah, dahulu mungkin iya hutan tapi sekarang tempat itu sudah berubah menjadi pemukimanan masyarakat tempatan. Kesalahan negara selanjutnya adalah ketika mereka melihat lokasi itu menggunakan helicopter milik perusahaan hanya melakukan potret dari atas saja sehingga kebun sagu kami dari atas hijau seperti hutan, tiba-tiba izin langsung dikuasai oleh perusahaan kami masyarakat Gunung Tohor dan seluruh kepala desa yang tergabung sampai kapanpun perjuang membela yang menjadi hak kami dan ini warisan dari nenek moyang kami. 
Kemudian wawancara dengan staf pemerintahan di Desa Lukit Junaidi juga menyebutkan bahwa: Ketika konflik masih memanas luar biasa dulu wilayah kami ini disorot oleh pusat karena, disini dulu sangking emosi nya masyarakat menolak datangnya perusahaan yang menguasai 20.000 hekter wilayah di sekitaran desa kami ini memperlihatkan tidak ada sebatangpun kebun sagu kami yang tidak masuk ke dalam wilayah konsesi mereka. Bahkan ketika itu kemarahan masyarakat sampai membakar alat PT. RAPP beserta operatornya. Dan pihak kepolisian langsung menangkap siapa yang menjadi dalang dan otak pelaku pembakaran tersebut, namun yang menjadi Target Operasi (TO) dalam peristiwa ini yang sangat banyak yaitu sekitar 17 orang.

\section{Gambar 4.1 Bagan Analisa Konflik Perusahaan dan Masyarakat (Vertikal) Berubah Menjadi Masyarakat dengan Masyarakat (Horizontal)}

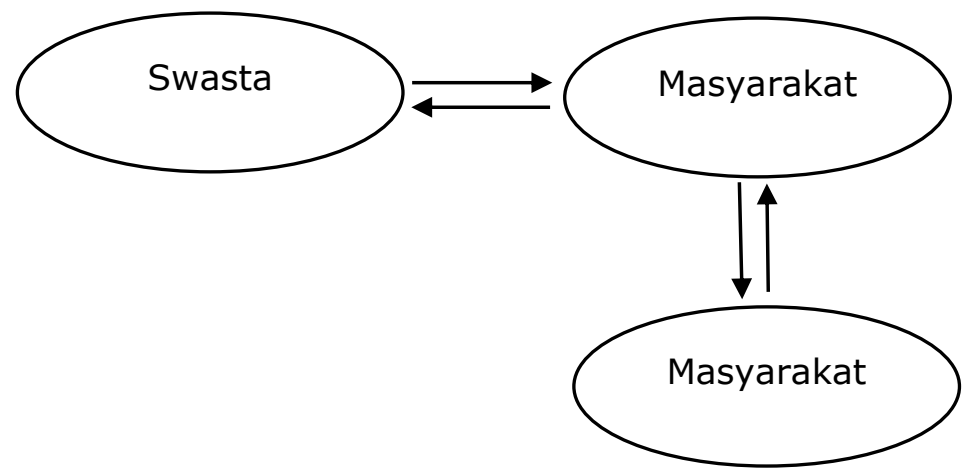

Selanjutnya berdasarkan wawancara dengan Direktur Utama PT. RAPP Rudi Fajar menyampaikan bahwa: Kami selaku dunia usaha hanya bermain pada peraturan yang berlaku di negara ini ketika izin konsesi kami pegang maka suatu wilayah tertentu bisa kami tanamani bibit akasia dan itu juga kami lakukan karena sudah mendapat izin dari pemerintah selaku yang mendapatkan mandate dari rakyat. Jadi apabila ada masyarakat yang menyerang kami dan melakukan pembakaran terhadap alat dan operator kami maka oknum masyarakat itu akan dihukum sesuai dengan hukum yang berlaku di negara kita ini.

Dari penjelasan seluruh informan di atas dapat peneliti interpretasikan bahwa walaupun Provinsi Riau merupakan wilayah yang memiliki sumber daya yang besar negara selaku pihak yang mempunyai kewenangan penuh untuk mengelola dan mengatur hasil alam yang ada di Provinsi Riau tidak mampu meningkatkan perekonomian masyarakat di sekitar perusahaan beroperasi, pekerja yang direkrut oleh perusahaan sebagian besar berasal dari luar daerah Riau, alasan perusahaan sangat klasik yakni masyarakat tempatan tidak memiliki kemampuan yang diinginkan oleh perusahaan, paling masyarakat disekitar kawasan hutan tanaman industri walaupun ada yang direkrut oleh perusahaan hanya menempati posisi sebagai security atau penjaga keamanan perusahaan. Sudah menjadi realitas juga 
bahwasanya pemerintah yang memiliki mandat sekarang lebih membela kepentingan perusahaan dari pada membela kepentingan masyarakat sekitar kawasan hutan tanaman industri. Dan terkadang yang diterima oleh masyarakat di sekitar perusahaan hanya menerima limbah yang hanya akan mendatangkan penyakit bagi masyarakat di sekitaran konsesi dan kawasan perkebunan sawit.

Kuatnya jaringan yang dimikili oleh perusahaan menjadikan perusahaan seolaholah sebagai lembaga yang tidak terkalahkan dikarenakan mereka telah terkoneksi sampai ke istana negara jadi Kementerian Lingkungan Hidup dan Kehutanan Republik Indonesia hanya melaksanakan perintah dari atasan mereka yang lebih tinggi begitu seterusnya sampai ke tingkatan pemerintah yang lebih rendah. Ditambah lagi perusahaan telah memberikan beasiswa ke kampus-kampus, memberikan bantuan Al-Qur'an ke masjid-masjid dan bahkan wartawan lokal diberangkatkan umroh oleh perusahaan menyebabkan pencitraan dan pemberitaan perusahaan sang penguasa hutan jutaan hektar selalu pemberitaan yang positif dan yang baik-baik saja.

Pengaruh pemerintah pusat terhadap hutan biasanya berdasarkan penguasaan atas kebijakan, kegiatan kehutanan atau kepemilikan hutan. Di negara yang kaya dengan sumberdaya hutan seperti Indonesia, penguasaan oleh negara seringkali terpusat pada Kementerian Lingkungan Hidup dan Kehutanan. Unsur masyarakat dapat mempengaruhi melalui jejaring informal, gerakan sosial, atau pun organisasiorganisasi resmi seperti Lembaga Swadaya Masyarakat (LSM). Tetapi pada praktiknya masyarakat di sekitaran konsesi hutan tanaman industri kurang memiliki pengaruh resmi terhadap sumber daya hutan yang bernilai tinggi.

\section{Kesimpulan dan Saran}

\subsection{Kesimpulan}

Dari hasil penelitian di atas maka dapat disimpulkan bahwa community participation yang ada di Provinsi Riau tidak bisa terlalu banyak berkontribusi dalam menjaga kawasan hutan secara komprehensif karena kebijakan dari Kementerian Lingkungan Hidup dan Kehuatanan Republik Indonesia itu sendiri memang untuk mengolah kawasan hutan menjadi kawasan yang produktif dan ini akan mendatangkan pemasukan secara financial kepada keuangan Negara. Selanjutnya kebijakan pemberian konsesi maupun izin perusahaan sawit semuanya berada di tangan Pemerintah dan berkolaborasi dengan pemilik modal dan masyarakat yang ada di kawasan hutan hanya menerima effect berupa limbah perusahaan dan konflik baik itu konflik secara vertical (konflik antara masyarakat dan perusahaan yang dibelakangnya ada pemerintah) maupun konflik secara horizontal (konflik masyarakat 
penolak kehadiran perusahaan dengan masyarakat yang mendukung kehadiran perusahaan.

\subsection{Saran}

Saran yang bisa penulis berikan yaitu pemerintah harus lebih serius dalam menjaga kawasan hutan dari pengrusakan yang terjadi di Provinsi Riau dan jangan bernegosiasi dengan swasta. Serta penegakan hukum betul-betul menjadi prioritas utama kepolisian yang ada di Provinsi Riau sehingga dengan demikian akan memberikan effect kepada perusahaan yang sengaja melakukan pengrusakan kawasan hutan.

\section{DAFTAR PUSTAKA}

agusti, R. 2012. "Pengaruh Partisipasi Penyusunan Anggaran Terhadap Kinerja Aparatur Pemerintah Daerah Dengan Dimoderasi Oleh Variabel Desentralisasi Dan Budaya Organisasi (Studi Kasus Pada Pemerintah Kabupaten Bengkalis)." Jurnal Ekonomi Universitas Riau.

Akbar, Muh. Firyal, Srihandayani Suprapto, And Surati Surati. 2018. "Partisipasi Masyarakat Dalam Perencanaan Pembangunan Di Desa Jatimulya Kabupaten Boalemo." Publik : (Jurnal Ilmu Administrasi).

Erman I. Rahim. 2004. "Partisipasi Dalam Perspektif Kebijakan Publik." Perspektif Kebijakan Publik.

Hernawati, D. 2013. "Partisipasi Masyarakat Dalam Pengelolaan Sampah Berbasis $3 r$ (Reduce, Reuse Dan Recycle) (Studi Pada Tempat Pengelolaan Sampah Terpadu Di Desa Mulyoagung Kecamatan Dau Kabupaten Malang)." Jurnal Administrasi Publik Mahasiswa Universitas Brawijaya.

Janelle Plummer And John G Taylor, 2004. Community Participation In China Issues And Processes For Capacity Building. Typesetting By Long House, Cumbria Uk Printed And Bound In The Uk By Cromwell Press Ltd

Larasari, Endang. 2008. "Reformasi Pelayanan Publik (Public Services Reform) Dan Partisipasi Publik." Dialogue.

Lubis, Asri. 2009. "Upaya Meningkatkan Partisipasi Masyarakat Dalam Pembangunan." Jurnal Tabularasa Pps Unimed.

Magriasti, Lince. 2011. "Arti Penting Partisipasi Masyarakat Dalam Kebijakan Publik Di Daerah: Analisis Dengan Teori Sistem David Easton." Proceeding Simposium Nasional Otonomi Daerah 2011.

Nurmalita, Novatiani Dan. 2000. "Pengaruh Akuntabilitas Publik, Partisipasi Masyarakat 
76 | Rauf, Zainal, Wardana, Maulidiah Community Participation...

Dan Transparasi Kebijakan Publik Terhadap Pengawasan Keuangan Daerah ( Apbd ) Di Dprd Kota Bandung." Universitas Widyatama.

Nuring Septyasa Laksana. 2013. "Bentuk-Bentuk Partisipasi Masyarakat Desa Dalam Program Desa Siaga Di Desa Bandung Kecamatan Playen Kabupaten Gunung Kidul Provinsi Daerah Istimewa Yogyakarta." Kebijakan Dan Manajemen Publik.

Pribadiningtyas, D. 2013. "Partisipasi Masyarakat Dalam Rehabilitasi Hutan Mangrove (Studi Tentang Peran Pemerintah Dalam Meningkatkan Partisipasi Masyarakat Untuk Rehabilitasi Hutan Mangrove Di Badan Lingkungan Hidup Kota Probolinggo)." Jurnal Administrasi Publik Mahasiswa Universitas Brawijaya.

Sagita, Novie Indrawati. 2016. "Partisipasi Warga Masyarakat Dalam Penilaian Kinerja Kecamatan Di Kota Bandung." Cosmogov.

Sigalingging, Angelius Henry, And Warjio. 2014. "Partisipasi Masyarakat Dalam Perencanaan Pembangunan (Studi Kasus Pada Kecamatan Sidikalang Kabupaten Dairi)." Jurnal Administrasi Publik.

Turner, J.S., \& Hulme, D.B. 1997. Lifespan Development (5th Ed). Orlando: Holt, Rineheart And Winston, Inc.

Wolenberg Dkk, 2009. Desentralisasi Tata Kelola Hutan Politik, Ekonomi, Dan Perjuangan Untuk Menguasai Hutan Di Kalimantan Indonesia. Harapan Prima; Jakarta. 